relapse when the steroid dose was lowered after a further remission on a higher steroid dose certainly suggests a relationship between treatment and proteinuria. In the two cases where the urine became protein-free one (Case 4) showed a membranous lesion, and one (Case 11) a mixed proliferative and glomerular lesion.

It is clear that the results so far achieved with steroid therapy in adult nephrosis should be interpreted with caution. The disease is subject to remissions and exacerbations, and procedures to control oedema, such as high-protein, low-salt diets, or diuretics, may in themselves result in lessening of protein excretion in the urine. Rosenheim and Spencer (1956) described three of a group of 13 adult nephrotics in whom the urine became protein-free on simple measures to control oedema, and in a further three cases the protein excretion diminished markedly. The reported results with steroid therapy are no better.

\section{Summary}

Twenty-six cases of the nephrotic syndrome in the adult have been treated with prolonged steroid therapy. All cases were diagnosed, either on percutaneous renal biopsy or on clinical grounds, as being due to glomerulonephritis. The effect of steroid therapy was assessed chiefly by observation of the daily excretion of protein in the urine.
Of the 13 cases in which renal biopsy was performed one showed no definite glomerular lesion. The protein excretion in this case fell to less than $1 \mathrm{~g}$./day. In the remaining 12 cases the glomeruli showed varying degrees of cellular proliferation and capillary wall thickening. The urine of two of these patients became protein-free on treatment and in a further two cases protein excretion fell to less than 1 g. $/ 24$ hours.

In none of the remaining 13 cases did the urine become protein-free, but in five the protein excretion diminished to less than $1 \mathrm{~g} . / 24$ hours.

We wish to thank colleagues who referred patients, and also Mr. Desmond Neill for many of the biochemical determinations.

\section{REFERENCES}

Arneil, G. C. (1961). Lancet, $2,1103$.

Blainey, J. D., Brewer, D. B., Hardwicke, J., and Soothill, J. F. (1960) Quart. F. Med., 29, 235.

Burch, R. R., Pearl, M. A., and Sternberg, W. H. (1962). Ann. intern. Med., 56, 54.

Charlton, D., Latner, A. L., Platt, J. W., Smart, G. A., Thompson, R. B., and Walker, W. (1958). Acta med. scand., 16i, 33.

Eales, L. (1959). S. Afr. F. Lab. clin. Med., 5, 125.

Johnson, J. R., and Reader, R. (1959). Aust. Ann. Med., 8, 200.

Lange, K., Strang, R., Slobody, L. B., and Wenk, E. J. (1957). Arch. intern. Med., 99, 760.

Peters, J. H. (1942), 7. biol. Chem., 146, 179.

Rosenheim, M. L., and Spencer, A.'G. (1956). Lancet, 2, 313.

Ross, E. J., and Smith, J. F. (1963). Quart. F. Med., 32, 65.

Sharpe, A. R., and Unger, A. M. (1959). Arch. intern. Med., 104, 684

\title{
Rapid Quantitative Barbiturate Estimation
}

\author{
A. S. CURRY,* M.A., PH.D., F.R.I.C.
}

Brit. med.F., 1964, 1, 354-355

A recent report (Curry, 1963a) gave a method of screening 2-ml. blood samples for barbiturate. This involved the use of magnetic stirring with chloroform, removal by suction of the aqueous layer, and, after washing, reaction to form chloroform-soluble mercury barbiturate. After removal of excess mercury a positive reaction shows itself as an orange colour on addition of dithizone solution.

It has been found possible to adapt the method to give a quantitative assay. This greatly increases its value, because estimation of the severity of the poisoning can now be made without recourse even to a colorimeter. The time for the analysis remains at five to eight minutes.

The modification consists in titrating the mercury barbiturate in the chloroform layer with a standard dithizone solution. By stirring with $0.5 \mathrm{~N}$ ammonia between successive additions the end-point is seen as a darkening of the chloroform layer and the appearance of a yellow colour in the ammonia.

\section{Method}

The apparatus is essentially similar to that described before (Curry, 1963a), but it has been found more convenient to decrease the size of the beaker to $50 \mathrm{ml}$. The optical density of the dithizone solution in chloroform at $605 \mathrm{~m} \mu$ has been increased to 3 ( $15 \mathrm{mg}$. in $400 \mathrm{ml}$.).

One millilitre of blood and $2.5 \mathrm{ml}$. of phosphate buffer $(\mathrm{M} / 15$ at $\mathrm{pH} 6.95)$ are magnetically stirred with $15 \mathrm{ml}$. of chloroform for three minutes. The aqueous layer is removed by suction and by washing with two $15-\mathrm{ml}$. aliquots of water in the usual way. It is important at this stage not to remove any of the chloroform layer ; if a trace is inadvertently lost it is made up by dropwise addition until the level again reaches the lower end of the suction-tube. The chloroform layer is then stirred for two minutes with $1 \mathrm{ml}$. of mercury bicarbonate solution containing $200 \mu \mathrm{g}$. of mercury ion per ml. After settling, $15 \mathrm{ml}$. of water is added and then immediately removed by the suction-tube. It is essential to remove as much as possible of the aqueous layer. If as little as $0.2 \mathrm{ml}$. remains this will give a subsequent positive blank value equivalent to 0.3 mg. of barbiturate per $100 \mathrm{ml}$. of blood; $3 \mathrm{ml}$. of $0.5 \mathrm{~N}$ ammonia solution is pipetted on top of the chloroform layer followed by successive 1-ml. aliquots of dithizone in chloroform solution. After each addition of dithizone the solution is stirred and the layers are allowed to separate. The end of the titration is seen as the appearance of a green darkening to the previously orange chloroform layer; the ammonia layer also takes up the unchanged dithizone and goes yellow.

Each millilitre of dithizone solution corresponds to $1 \mathrm{mg}$. of barbiturate per $100 \mathrm{ml}$. of blood.

At low barbiturate concentrations ( $2 \mathrm{mg} . / 100 \mathrm{ml}$. or less) the blank value is of great importance. If, before adding dithizone, the excess mercury reagent is removed by washing with an additional $15 \mathrm{ml}$. of water the blank is reduced to zero. Such washing, however, results in loss of mercury barbiturate from the chloroform layer, and recovery of amylobarbitone, pento-

* Home Office Forensic Science Laboratory, Harrogate. 
barbitone, quinalbarbitone, and butobarbitone drops to $70 \%$; for phenobarbitone and cyclobarbitone it is approximately $50 \%$.

Mercury barbitone is relatively soluble in water, and the method is less sensitive for barbitone. This is convenient because considerably higher blood levels of barbitone are necessary to account for coma than for the shorter-acting barbiturates.

Glutethimide ("doriden") and bemegride ("megimide") react in the same way as the barbiturates at approximately the same concentrations.

Now that thin-layer chromatography can be used for the separation of barbiturates (Sunshine, Rose, and LeBeau, 1963), identification and assay are within the ability of any hospital laboratory, and the probable time the patient will remain in coma, if infection does not supervene, can be assessed (Curry, 1963b).

\section{Summary}

Barbiturate concentrations in $1 \mathrm{ml}$. of blood can now be assessed in a little over five minutes without recourse even to a colorimeter.

Professor G. Mannering first drew my attention to the fact that mercury dithizonate is stable in alkaline solution and so provided the impetus for this work. I am also grateful to Mr. E. R. Rutter and Mr. R. G. L. Osborne for their assistance.

\section{REFERENCES}

Curry, A. S., (1963a). Brit. med. f., 2, 1040.

(1963b). Poison Detection in Human Organs, p. 45. Thomas, Springfield, Illinois.

Sunshine, I., Rose, E., and LeBeau, J. (1963). Clin. Chem., 9, 312.

\section{Medical Memoranda}

\section{Controlled Trial of Oxethazaine as an Analgesic in Duodenal Ulcer}

Brit. med. F., 1964, 1, 355-356

Oxethazaine is a surface analgesic (N,N-bis-(N-methyl-Nphenyl-t-butyl-acetamide)-beta-hydroxyethylamine) of which significant amounts remain in the un-ionized form at low $p \mathrm{H}$ levels (Schwartz and Spertus, 1962). When given in 20-mg. doses together with aluminium hydroxide gel B.P. and magnesium hydroxide ("mucaine"), it is said to relieve dysphagia in radiation oesophagitis (Sklaroff and Karayannis, 1962), and to relieve pain due to reflux oesophagitis (Jankelson and Jankelson, 1959 ; Ryall, 1962), chronic gastritis (Deutsch and Christian, 1959), and duodenal ulcer (Hollander, 1960).

The latter claim has been tested by a carefully controlled trial. which is the subject of this communication.

\section{Material and Method}

Thirty-two successive out-patients of both sexes, with current pain-food-relief dyspepsia, in whom a duodenal ulcer had been seen radiologically during the recent month, were admitted to a double-blind trial in which the patients acted as their own controls.

Each patient was instructed to continue his present dietary treatment, and in addition to take two teaspoonfuls of the medicine given to him 10 to 15 minutes before each meal and at bedtime. He was asked to record each day at 7 p.m., on the chart provided, the amount of pain he had suffered in the previous 24 hours. This he scored as follows: definite pain $=2$, some discomfort $=1$, no pain $=0$. All patients were seen by the same physician at weekly intervals, when complaints were elicited. Each subject was then given a fresh pain chart, after which he exchanged his completed chart and empty bottle at the hospital dispensary for a further week's supply of medicine.

The hospital pharmacist started alternate patients on mucaine; others began with the control, which differed from the mixture under trial only in that it did not contain oxethazaine. At each weekly visit patients changed to the other treat- ment group, so that at the completion of the trial period of one month each had taken mucaine for a total of two weeks and the control also for two weeks.

At no time did the physician know to which group any patient belonged.

\section{RESULTS}

For each patient the daily pain scores were added to give two totals, one for the periods in which mucaine was taken and the other for the periods in which the control was taken. The difference between these total scores was the basis for the statistical analysis (see Table).

Pain Scores for Individual Patients During Treatment with Mucaine and Control

\begin{tabular}{|c|c|c|c|}
\hline \multirow{2}{*}{ Patient } & \multicolumn{2}{|c|}{ Pain Score } & \multirow{2}{*}{ Difference } \\
\hline & Mucaine ( + ) & Control (-) & \\
\hline $\begin{array}{r}1 \\
2 \\
3 \\
4 \\
5 \\
6 \\
7 \\
8 \\
9 \\
10 \\
11 \\
12 \\
13 \\
14 \\
15 \\
16 \\
17 \\
18 \\
19 \\
20 \\
21 \\
22 \\
23 \\
24 \\
25 \\
26 \\
27 \\
28 \\
29 \\
30 \\
31 \\
32\end{array}$ & $\begin{array}{r}25 \\
20 \\
6 \\
5 \\
16 \\
9 \\
6 \\
2 \\
0 \\
5 \\
12 \\
2 \\
8 \\
12 \\
5 \\
11 \\
3 \\
0 \\
0 \\
24 \\
17 \\
5 \\
8 \\
7 \\
13 \\
18 \\
5 \\
6 \\
9 \\
16 \\
0 \\
13\end{array}$ & $\begin{array}{r}26 \\
16 \\
4 \\
8 \\
14 \\
12 \\
4 \\
4 \\
3 \\
6 \\
11 \\
2 \\
9 \\
13 \\
2 \\
11 \\
2 \\
4 \\
0 \\
18 \\
18 \\
8 \\
5 \\
11 \\
13 \\
20 \\
6 \\
8 \\
4 \\
12 \\
2 \\
13\end{array}$ & $\begin{array}{r}-1 \\
4 \\
2 \\
-3 \\
2 \\
-3 \\
2 \\
-2 \\
-3 \\
-1 \\
1 \\
0 \\
-1 \\
-1 \\
33 \\
0 \\
1 \\
-4 \\
0 \\
6 \\
-1 \\
-3 \\
3 \\
-4 \\
0 \\
-2 \\
-1 \\
-2 \\
5 \\
4 \\
-2 \\
0\end{array}$ \\
\hline
\end{tabular}

The average difference was not statistically significant $\left(t_{n-1}\right.$ $=0.066$, and was in fact smaller than might have been expected to arise by chance. 